\author{
Wojciech W. Gasparski \\ Kozminski University \\ Department of Entrepreneurship and Ethics in Business \\ e-mail:wgaspars@kozminski.edu.pl
}

\title{
A brief history of Business Ethics here and now*
}

\begin{abstract}
The article is a review of issues connected with business ethics and corporate social responsibility (CSR) in the last 20 years. Two decades have passed since the Sixth Polish Philosophical Congress took place in Torun, where-for the first time in the history of Polish philosophical conventions-business ethics was recognized as a philosophical sub-discipline. It manifested itself in a special subsection of the Congress devoted to the topic, which was also kept at the next congress meetings. The paper is not a full review and most likely is not free from subjectivism. This is partly due to the fact that the subject matter falls within the scope of the philosophy of practicality - as the author interprets and refers to the philosophical system of Tadeusz Kotarbiński.
\end{abstract}

Keywords: business ethics, ethics of economics, ethical infrastructure, praxiology, corporate social responsibility

JEL Classification: M14

Last year marked two decades since the Sixth Polish Philosophical Congress took place in Torun, where - for the first time in the history of Polish philosophical conventions - business ethics was recognized as a philosophical sub-discipline. It manifested itself in a special subsection of the Congress devoted to the topic, which was also kept at the next congress meetings. The anniversary seems to be a suitable occasion to review the subject matter in the context of the last two

\footnotetext{
* The article is an updated version of the paper published in Polish in Etyka biznesu i zrównoważony rozwój. Interdyscyplinarne studia teoretyczno-empiryczne, 2016, 1, 21-35
} 
decades. It will not be a full review and probably will not be free from subjectivism. This is partly due to the fact that the subject matter falls within the scope of the philosophy of practicality - as I interpret and refer to the philosophical system of Tadeusz Kotarbiński (Gasparski, 1993a).

At the Toruń congress, I had the honor to present the paper „Działalność gospodarcza z punktu widzenia filozofii: między prakseologią a etyką" ["Economic activity from the philosophical perspective: between praxiology and ethics"] (Gasparski, 1996). During the presentation, I called for the recognition of economic activity as serious action, which was based on Józef Maria Bocheński's distinction between cognition as serious thinking and thinking in general (1992, p. 16). The seriousness requires us to treat the goal of an action and the way-i.e., the meansof achieving it seriously. In the case of thinking, which aims at acquiring knowledge (cognitive value) as well as in the case of economic activity, the purpose of which is to get benefits (economic value), the goal cannot justify the means. Therefore, it is necessary to take care of the positive evaluation of actions not only in praxiological categories, i.e., according to two main criteria: effectiveness and efficiency, but also in terms of ethicality that sets the framework (norms) of actions admissible in a given culture or across cultures. These three dimensions - The Triple E-are the necessary condition for an action to be characterized by the seriousness of the highest degree - wisdom as a kind of technology, ${ }^{1}$ presupposing that an acting man is a person of strong character, ${ }^{2}$ as Bocheński wrote. The scholar believes that this is precisely what praxiology recommends. In addition, referring to Tadeusz Kotarbiński's concept of "small philosophy" (cf. Gasparski, 2006, pp. 13-19), I asserted that business ethics could be seen as "small ethics of management." Small, because it does not aspire to create an Arcadia of economic life, but it realistically endeavors to civilize business, i.e., professionalize it, which requires professional and moral competence (Gasparski, 1966).

The postulate of small business ethics converges with the concept of bounded rationality formulated by the Nobel Prize winner Herbert A. Simon, on which he spoke at the international conference "Praxiologies and the Philosophy of Economics", which preceded the debate in Torun and was convened in Warsaw in 1988 by the praxiological community (Auspitz et al., 1992). It was organized with the support of the Austrian Cultural Institute and the SABRE Foundation from the United States. The conference was also attended by the doyen of the American philosophy of economics, Kenneth E. Boulding, the systems theorist, George

\footnotetext{
${ }^{1}$ Mario Bunge expresses a similar view regarding praxiology and ethics: "The reason for regarding philosophical ethics and praxiology as technologies and, indeed, as the philosophical technologies, is this. Technology is about designing and planning, maintaining and repairing. So are moral philosophy and praxiology. In fact, to face a moral or praxiological problem, to take responsibility for it, and to reflect on the means to solve it in the light of available knowledge and resources, may be regarded as a technological problem. Conversely, to face a technological problem in any depth necessitates invoking general praxiological concepts and principles. And to tackle a problem with social responsibility requires some ethical concepts and principles" (Bunge, 1999). For similar reasons, Kotarbiński (2003) defined praxiology as a methodology.

${ }^{2}$ That is, having virtues synonymous with the integrity of character (MacIntyre, 1996).
} 
J. Klir, the epistemologist of practice, Donald A. Schön, the philosopher from the University of Pennsylvania in Philadelphia, Henryk Hiż - a student of Tadeusz Kotarbiński, as well as numerous scholars from Poland and abroad.

Simon criticized the physicalization of economics, stating:

What is startlingly absent from the empirical literature of classical economics is evidence of optimization based on the direct observation of the behaviour of economic actors. Milton Friedman (1953), of course, in his celebrated essay on methodology in economics, has sought to make a virtue of this deficiency. He argues that a theory cannot be judged by the realism of its assumptions, but only by its efficacy in making predictions. [...]

The second flaw in Friedman's argument is his claim that unrealism in the assumptions of a theory is a good thing, or that it is even acceptable. [...] Among the inferences that can be drawn from any theory, hence among its predictions, is the truth of its assumptions. (1989, pp. 142-143)

A practice methodologist, a praxiologist, would say that practical solutions should be accurate, and in order to become accurate, they should result in relevant changes (i.e. proper). This is a requirement laid down for solutions of design, analogous to the criterion of truth for scientific solutions. The conceptual preparation of actions leading to such changes is the distinguishing methodological feature of design - as specified in the design methodology which I proposed some time ago (Gasparski, 1993b). Design, on the other hand, is the methodological distinguishing feature of applied sciences, which Kotarbiński and Simon demonstrated independently of each other. What is more, the latter received the Nobel Prize for, among other things, the concept of bounded rationality, indicating that it is not perfection, or utter perfection, that provides the basis for the choices people make on the market (and not only there), but satisfaction. Thus, it can be concluded that the difference between the perfection of "econo-physicists"- - however it would be understood - and bounded rationality, which is characteristic of entities making real choices, lies in the missing economic "coefficient of friction" (Gasparski, 2009a).

It is worth mentioning that Boulding, who participated in the conference, was already well-known to Polish readers for his works that had been translated into Polish and published by the Polish Publishing Institute (Polish: Polski Instytut Wydawniczy) (Grosfeld, 1985), in particular, for an article on business ethics (Boulding, 1985). Based on this article (pp. 59-69), the following noteworthy theses can be formulated: 
ETHICS AND BUSINESS

The 25 theses according to K. E. Boulding

1. Every human behavior is driven by a system of values, i.e., a certain system of preferences, a personal ethical system.

2. Even if this behavior is arbitrary and "irrational", it is probably because a given person attaches high value to arbitrariness and "irrationality".

3. Faced with a set of images of the future, a person evaluates them and chooses one.

4. The choice of the way that we choose one "correct" system of values out of many is (by design) an ethical system of values.

5. It is not possible to prove statements of an ethical theory a priori.

6. Each culture (subculture) has an ethical system by which it is created and which it creates.

7. The dynamic nature of society relies on the existence of a certain tension between the explicit and implicit value systems.

8. A society with unattainable ideals is characterized by high dynamics, while a society with ideals "within the possibilities" remains stagnant.

9. It is necessary to reject the type of ethical relativism in accordance with which all ethical answers are equally legitimate.

10. If a given society does not consider the value of its culture, it is threatened with stagnation or a downfall.

11. A business society is a social system organized primarily by exchange institutions.

12. A social system is created by the relations between persons, or - more precisely - between the roles performed by these persons.

13. The fundamental problem of a social system lies in the conflict of roles.

14. The relations between roles come into the following categories:

(a) threat ("do something nice for me, or else I will do something nasty to you"), or deterrence ("if you do something bad to me, I will do something bad to you") [a zero-sum game, the so-called prisoner's dilemma];

(b) exchange, or promise ("if you do something nice to me, then I will do something nice to you") [a non-zero-sum game];

(c) integration ("I want the same thing as you").

15. No society is purely a business society.
16. In addition to exchange institutions (corporations, banks, stock markets, unions, etc.), every society has a government (managing the threat system) and integrative institutions (family, church, school, club, etc.).

17. Whatever undermines an exchange institution and its organizing force undermines the business system.

18. The issues undermining exchange institutions:

(a) individual systems of values (lack of
simple honesty, deficiency of Puritan virtues, cynicism);

(b) political conceptions (no basic governmental framework);

(c) the abstract character of an exchange system (lack of integration, lack of personal relations that would be richer than relations of exchange);

(d) lack of emotional involvement (a business society as a cold institution, the inability to evoke feelings).

19. The development of integrative institutions is indispensable for a business society to survive, since business institutions - being instrumental in character - are not able to develop integration systems on their own.

20. The shortage of integrative institutions poses a threat that management units may develop personal ethics which is harmful to market institutions.

21. The internalization of basic virtues of honesty and reliability is gradually weakened if a person devotes all his or her life to accounting books and focuses solely on details of economic life and organization.

22. A system of exchange provides individuals with an opportunity to gain personal benefits by compromising their moral principles.

23. A society that devotes a disproportionate part of its life and energy to the system of exchange can undermine this system.

24. The attempts of systems based on coercion (e.g. statist, military) or the involvement of integrative institutions (church, school, etc.) into the economic sphere - so the exchange system, may prove futile.

25. The stability of a social system depends on the proportions between the three main categories (organizing factors). 
At the conference, Boulding addressed issues related to the methodology of economics, which he concluded by indicating the connection between economics and what he described as integrating factors, i.e., parts of the social system related to the social bond, identity, legitimacy, loyalty, love, etc. He encouraged dreaming about an integrated theory of humanity, of which economics would be an essential part (Boulding, 1989).

Also, during the conference, Schön put the following task before the praxiologists:

It is timely then [...] to reconsider the question of professional knowledge. Perhaps there is an epistemology of practice that takes fuller account of the competence practitioners sometimes display in situations of uncertainty, complexity, uniqueness, and conflict. Perhaps there is a way of looking at problem-setting and intuitive artistry that presents these activities as describable and as susceptible to a kind of rigor that falls outside the boundaries of technical rationality. [...] We should be turning the puzzle of professional knowledge on its head, not seeking only to build up a science applicable to practice but also to reflect on the reflection-in-action already embedded in competent practice. (1992, pp. 163-183)

Attention was also drawn to the importance of a comprehensive approach to economic issues due to their context (cf. also Bocheński, 1993). Hiż delivered a report which was significant from the perspective of business ethics. It warned:

Although ethical values must be complemented by praxiological values, the two kinds should not be confused. Efficiency can serve any purpose, as evidenced by the destruction of European Jews by the Nazis. It is good to be efficient in good; it is evil to be efficient in evil. The same is true in economics. We cannot help Adam [i.e. a person in need-author's note] without adopting sound economic procedures. Economics without an ethical goal of minimizing the suffering may be neutral ethically, but when it helps the rich at the expense of the poor, it is evil. (Hiż, 1992, p. 428).

Another conference preceding the Philosophical Congress in Torun was the First National Conference on Business Ethics, organized in Łódź in 1994 by the Learned Society of Praxiology (Polish: Towarzystwo Naukowe Prakseologii) and the Educational Enterprise Foundation (Dietl \& Gasparski, 1997), during which a scheme for developing business ethics in Poland was devised. According to Gasparski (1997, pp. 32-34), its elements, include:

(1) Definition: business ethics is a discipline practiced at the intersection of ethics as a branch of practical philosophy and the managerial activity that is mostly associated with the economy, banking, trade and other forms of entrepreneurship. It is a systematic study of moral issues (ethos) arising in business, industry as well as other related types of activities and practices. Other subjects of the ethical reflection include beliefs of acting human beings, norms, values and courses of action. 
(2) Indispensability: All human activity, economic in particular, is governed by moral norms. Every company must follow the code of basic norms of honesty, as being honest is the best course of action.

(3) Purposefulness: A transformation of the political system and a change of the economic system in Poland require changes in the behavior of people who participate in business. The fixed routines of social behavior should not be transferred onto behaviors in the economy that are in cooperation with developed countries. Business ethics is related to the efficiency and organization of work, the quality of manufactured products and profit, as well as the recognition of Polish entrepreneurs as reliable partners.

(4) Favorable factors: The intellectual tradition of practical philosophy in Poland, on a footing of which the study of efficient action-praxiology meets the study of morality - ethics, provides a basis for practicing business ethics as an interdisciplinary field of teaching and research. What constitutes a favorable factor is the interest in the circles of people that are associated with the Church. Researchers from countries that belong to international organizations declare their readiness to cooperate, which opens up an opportunity for Poland to establish relatively quickly business ethics as a separate discipline.

Three years later, under the auspices of the same organizations, the Second National Conference on Business Ethics took place (Łódź 1997) (Gasparski $\&$ Dietl, 2000), at which the ethical standards of the uniting Europe were presented. A professor of business ethics at Nyenrode Business University, Henk van Luijk, initiator of the European Business Ethics Network (hereafter: EBEN) and its first president, described the history of EBEN and pointed out four - as he put it- "concrete results that can be produced quite quickly in Poland as well as in other countries":

First, to start the work in this field, scholars dealing with the issues of ethics and business or planning will benefit from sharing their experiences and supporting each other. To achieve something new, one needs not only new ideas, but first and foremost-friends.

Second, those in the business world who are inherently sensitive to the moral aspects of market activity will gain allies where they would expect to find competitors or, at best, strangers who are locked away in their own scientific worlds.

Third, joint efforts of various parties make the public aware that responsible business is not solely a utopian idea, but a real possibility.

Fourth, people and companies operating in Poland and other European countries will benefit greatly from joint efforts to promote the application of moral principles in the business decision-making process (Luijk, 2000, p. 22). 
Did the programme presented at the First National Conference on Business Ethics and the guidelines set out by the EBEN president at the Second Conference gain the support of the Polish academic world and the business world? This question was asked at the Polish Congress of Business Ethics and Corporate Social Responsibility organized in Warsaw in 2009 by the Business Ethics Centre ${ }^{3}$ (Centrum Etyki Biznesu, hereafter: CEBI) of Kozminski University (Akademia Leona Koźmińskiego, hereafter: KU) as well as the Institute of Philosophy and Sociology of the Polish Academy of Sciences (Instytut Filozofii i Socjologii Polskiej Akademii Nauk, hereafter: IPS PAS). The panelists agreed that the programme undoubtedly led to academics' engagement in the subject matter, which was confirmed in the report on the state of business ethics in the world that explains:

A country like Poland has today around 44 different state-recognised universities. In almost all of them, there will be some form of business ethics or CSR teaching going on. The boom of business ethics and CSR clearly took place over the past ten years. (Rossouw \& Stückelberger, 2012, p. 223)

It was also found that

as the example of Poland above shows, even in Eastern Europe the penetration of business ethics has increased dramatically. For Eastern Europe one should make a further distinction between [...] countries like Poland, Hungary and the Czech Republic, where a majority of universities and business schools offer some form of training in the direction of business ethics, and Eastern European countries (e.g. Bulgaria, Belarus) where we could find almost nothing on offer. (p. 234)

When it comes to the implementation of the programme by the business world, the project of developing business ethics was certainly recognized; yet, there is no definite answer as to whether or to what extent words were turned into action. In the initial phase of the transformation, a kind of "middle schooler's syndrome" (Polish: "syndrom gimnazjalisty")—as we may call it—occurred. ${ }^{4}$ Some participants in economic life seemed to be affected by it. In a way, this phase was the time of their economic adolescence, similar to teenagers' maturing to adulthood, ergo, the period of individuation and the rejection of norms, and the pursuit of power in the business market. ${ }^{5} \mathrm{~A}$ characteristic feature of this period was the so-called

\footnotetext{
${ }^{3}$ Established in 1999.

${ }^{4}$ By "middle schooler's syndrome", I refer to behaviours that are characteristic of the young people who are in transition from elementary school to middle school, which an article on the behaviour of junior high school students describes in the following way: "The moment of maturation is related to the period of individuation, the rejection of norms, rebellion against parents and teachers, along with a dramatic increase in importance of our peer group. For the 13- and 14-year-old, the peer group and what it feels like to be in this group is most important. What their parents say, or what their beliefs really are, is less significant than what their peers think. As a result, the kids egg each other on and they do not have too many corrective mechanisms. [...] The primary objective of such a group is to seize power" (Ćwieluch, 2016, pp. 32-34).

${ }^{5}$ Such behaviours confirm the findings of the research conducted by the moral psychologist Jonathan Haidt, which indicate that emotions dominate our reflection. "The mind is divided like a rider on an elephant, and the rider's job is to serve the elephant. The rider is our conscious reasoning - the stream
} 
marginal morality, which Professor Aniela Dylus describes as conduct aimed at outwitting competitors. "In accordance with the principle of economy, the smallest possible 'input of morality' should [...] bring the greatest possible economic benefit” (2002, pp. 284-290).

For example, "Apel do świata polskiego biznesu" ["The Plea to the World of Polish Business"] (Gasparski, Lewicka-Strzałecka, Rok \& Szulczewski, 2002, pp. 18-20), issued at the conference organized in 2001 by CEBI together with the United Nations Development Program (hereafter: UNDP) in connection with the launch of the UN Global Compact initiative, received less attention than had been expected - not only in the business world, but it also did not receive proper coverage in the media, since the media is interested more in sensations (i.e. "scams") rather than in supporting good practices and social education. However, the fact that the European promotion of the Global Compact took place in Poland is a token of recognition for the contribution made to business ethics by the Polish academic world and the part of the business world that still remembered good commercial practice from older times, i.e., before the times of the centrally planned economy. It is evidenced by codes of best practice, such as those pointed out at the Second Congress of Polish Culture. Some of the examples include ${ }^{6}$ : The Canon of Best Financial Market Practices (the Polish Financial Supervision Authority); The Ethical Canon of an Entrepreneur (the Polish Confederation of Private Employers Lewiatan), which is open to all entrepreneurs; The Principles of Best Banking Practice (the Polish Banks Association); The Principles of Best Practices (the Conference of Financial Companies in Poland); The Best Practice for Public Companies (the Warsaw Stock Exchange); and The Code of Best Practice for Universities adopted by the Conference of Rectors of Academic Schools in Poland (Gasparski et al., 2010) as well as an increasing number of ethical codes drawn up by companies (NB business ethics are codified ethics). This is how the elements of the material ethical infrastructure of Polish business were formed.

The development of the intellectual, ethical infrastructure of business, i.e., of the assumptions made about participating in a business activity, met and still meets with resistance resulting from common stereotypes and beliefs, to which the doyen of Polish philosophers, Prof. Władysław Stróżewski, drew attention in the inaugural lecture at the Ninth Polish Philosophical Congress (Wisła 2012):

Perhaps the most important feature of convictions is their lack of reflection. Convictions are experienced the same way they were acquired-without thinking about their source or their cognitive value. [...] The lack of reflection is conducive to irrationality. Many of our convictions cannot be rationally explained. And yet, we insist upon them, dismissing any words of criticism towards them, or even

of words and images of which we are fully aware. The elephant is the other 99 percent of mental processes - the ones that occur outside of awareness but that actually govern most of our behavior. [...] If morality doesn't come primarily from reasoning, then that leaves some combination of innateness and social learning as the most likely candidates. [...] We're born to be righteous, but we have to learn what, exactly, people like us should be righteous about" (Haidt, 2014).

${ }^{6}$ The Business Ethics Centre of KU \& IPS PAS played a part in the preparation and implementation of these elements of ethical infrastructure. 
a simple thought or consideration. [...] We live in a world of convictions. The point is that these beliefs should be justified, based on the truth. And this, in fact, is a postulate of their transgression: the transition from convictions to amply justified beliefs. (Stróżewski, 2012, pp. 11-18)

What provided the encouragement to shift from convictions to well-founded beliefs as regards business ethics was the program of the above-mentioned Polish Congress of Business Ethics and Corporate Social Responsibility as well as the Manifesto drawn up by its participants (Gasparski \& Rok, 2010), proclaiming that:

In appreciation of what has been achieved so far in disseminating the ethical dimension of economic activity in Poland, the participants of the Polish Congress of Business Ethics and Corporate Social Responsibility held in Warsaw on December 9-10, 2009, recognize the need to undertake initiatives aimed at placing the same importance on this dimension as in the case of the ethical aspect of socially significant activities, such as scientific research or medicine.

Economic activity is also a serious endeavour, and thus, it requires analogous responsibility of all involved parties. Therefore, creating an ethical infrastructure and a strategy of corporate social responsibility should not be a concern of solely a few people and institutions. It is crucial that all stakeholders work together towards the civic economic republic as an essential component of the civil society of our country. Acting in the interests of the common good is a touchstone of patriotism in its contemporary positive sense.

Bearing in mind the global dimension of economic activity, we recognize that the manifesto "Global Economic Ethics: Consequences for Global Business" issued on October 6, 2009, on the initiative of the UN Global Compact, among others, deserves to be popularized in the economic life of Poland. Therefore, we appeal to business entities to clearly declare their willingness to act in accordance with the principles laid down in the Manifesto.

It is necessary to provide all-level education in the field of ethics and corporate social responsibility. The subject matter should be taken into account during employee training. The mass media have a major role to fulfill.

The manifesto "Global Economic Ethics: Consequences for Global Business" evokes the Golden Principle. Let us recall its two forms: (a) worded positively"Whatever you wish that others would do to you, do also to them" (Matthew), i.e., always act the way you would like others to act towards you; (b) worded negatively - "Do not do to others what you do not want done to yourself" (Confucius). The Manifesto states:

This Golden Rule of reciprocity, which for thousands of years has been acknowledged in all religious and humanist traditions, promotes mutual responsibility, solidarity, fairness, tolerance, and respect for all persons involved. Such attitudes or virtues are the basic pillars of a global economic ethos. Fairness in competition and cooperation for mutual benefit are fundamental principles of a sustainably developing global economy that is in conformity with the Golden Rule. 
In addition, the Manifesto pinpoints the basic values for global economic activity: non-violence and respect for life, justice and solidarity, honesty and tolerance, mutual esteem and partnership. In conclusion, the Manifesto says that the internationally accepted rules of conduct in economic life should be respected.

A previous document, also adopted under the auspices of the Global Compact, contained the principles for responsible management education, formulated in connection with the increasing involvement of the academic as well as the business world in the UN Global Compact Secretary General's initiative on responsible corporate activity in the globalized world. We were one of the first academic communities that joined this program (Gasparski, 2008). Here are the Six Principles for Responsible Management Education:

1. Purpose: We will develop the capabilities of students to be future generators of sustainable value for business and society at large and to work for an inclusive and sustainable global economy.

2. Values: We will incorporate into our academic activities, curricula, and organizational practices the values of global social responsibility as portrayed in international initiatives such as the United Nations Global Compact.

3. Method: We will create educational frameworks, materials, processes and environments that enable effective learning experiences for responsible leadership.

4. Research: We will engage in conceptual and empirical research that advances our understanding of the role, dynamics, and impact of corporations in the creation of sustainable social, environmental and economic value.

5. Partnership: We will interact with managers of business corporations to extend our knowledge of their challenges in meeting social and environmental responsibilities and to explore jointly effective approaches to meeting these challenges.

6. Dialogue: We will facilitate and support dialog and debate among educators, students, business, government, consumers, the media, civil society organizations and other interested groups and stakeholders on critical issues related to global social responsibility and sustainability.

The fact that the International Society of Business, Economics and Ethics (ISBEE) chose to hold the Fifth World Business Ethics Congress in Warsaw and to entrust the role of the host to Kozminski University was not only a token of appreciation of the place and organizer, but also the entire Polish community - both of academics and practitioners of economic life-involved in developing ethics and corporate social responsibility.

The Congress was held on July 11-14, 2012 and its main theme was Tradition and new horizons: towards the virtue of responsibility. It was attended by 311 participants from 44 countries of all continents (except Antarctica), 163 papers were presented (selected from 223 submitted ones) in 10 parallel thematic threads, 4 sessions each. ${ }^{7}$ Renowned scholars and practitioners were invited to deliver lectures on

\footnotetext{
${ }^{7}$ A selection of papers was published in the book Understanding Ethics and Responsibilities in a Globalizing Word (2016).
} 
carefully selected topics during 5 plenary sessions and to organize 18 interactive panel discussions, in which 103 panelists took part. The Congress was preceded by sessions devoted to the art of teaching business ethics and the professional development of junior researchers. Lech Wałęsa attended the inaugural plenary session as a guest of honor. The academic sessions of the Congress were dedicated to financial ethics, spirituality in business, economy and management, the transfer of knowledge in the field of business ethics and CSR, ecology, education, the ethics of management and economics, axiology, sustainable development, leadership, politics and corporate governance, and corporate social responsibility (CSR). The thematic interactive sessions dealt with an assessment of the 10-year progress of the UN Global Compact, education in making better moral decisions, responsible urbanization, and collective actions to solve complex social problems. Moreover, plenary sessions were held on the following topics: global perspectives on teaching business ethics and economics as well as the research in the field, sustainable development and future prospects for business ethics. At the closing session, prof. Patricia Werhane, president of ISBEE, asserted that it had been one of the bestorganized editions of the Congresses. She also suggested it might be a good idea if managers were obliged to make a promise modeled on the Hippocratic Oath. ${ }^{8}$

The Congress was an impulse for the Polish business ethics community, pointing the direction for further educational, research, practical and dissemination activities. And so, what deserves mentioning is the creation of the Department of Ethics in Business at KU (2013), the publication of the academic PWN textbook Biznes, etyka, odpowiedzialność [Business, ethics, responsibility] (Gasparski, 2013) which the Polish Economic Society awarded First Prize for the best economic textbook published in the recent years, the session of the Business Ethics Subsection at the Tenth Polish Philosophical Congress (Poznań 2015), and the creation of the coalition of business ethics spokespersons, which brings together specialists who have an advisory function in companies (The Global Compact Network Poland), which was done under the auspices of the Polish Commissioner for Human Rights and UNDP Global Compact Poland (2015).

The past two decades have been a time of increased mutual cooperation in the field of ethics and social responsibility - between not only national but also foreign and international centers and organizations. In the given period, the following centres remained particularly active: the Department of Philosophy at Kraków University of Economics, which regularly organized conferences devoted to various aspects of ethics in business activity; the Institute of Cultural Studies at Adam Mickiewicz University in Poznań, attached to which the Polish Business Ethics Association EBEN Poland has been operating since 2000; the Department of Microeconomics and Institutional Economics at Wrocław University of Economics; the Salesian School of Economics and Management in Łódź, annually organizing the "Ethics in Economic Life" conferences, which is currently continued by the Faculty of Economics and Sociology at the University of Lodz, Cardinal Stefan Wyszyński University and the Responsible Business Forum (http://

\footnotetext{
${ }^{8}$ Likewise, after the financial crisis, it was suggested that economists should make a promise as well (DeMartino, 2011; Gasparski, 2015).
} 
odpowiedzialnybiznes.pl/). The Business Ethics and Social Innovation Center, as well as the Business Ethics Department of Kozminski University, continue with the activities of CEBI and the former IPS PAS Research Team of Ethics in Economic Life, and in cooperation with the Learned Society of Praxiology (Polish: Towarzystwo Naukowe Prakseologii) and IPS PAS, hold annual conferences on current issues of ethics and corporate social responsibility, ${ }^{9}$ and since 1994 organized the monthly National Seminar on Ethics in Business, Economy and Management (Polish: Etyka w Biznesie, Gospodarce i Zarządzaniu), which was recently complemented with issues of business sociology.

The international cooperation consisted in participating in the annual conferences of EBEN, the European Academy of Business in Society (EABIS), the United Nations Development Program (UNDP) and many others, as well as taking part in research programs (for example: Pańkow, Rok, Strumińska-Kutra \& Woźniczko, 2010; Kamiński \& Sójka, 2013; Rok, 2013; Filek, 2013; Kuraszko, 2014; Fryzel, 2015), including those funded by the European Union. The cooperation with the International Society of Business, Economics and Ethics (ISBEE) - the organizer of the World Business Ethnic Congresses, which is held every four years- was of vital importance. Thus far, the Polish business ethics community has been represented at all Business Ethics Olympics - as these congresses are sometimes referred to. Special volumes dedicated to subsequent congresses (with the exception of the fourth congress ${ }^{10}$ ) were prepared and published by Transaction Publishers (since 2017 by Routledge) under the auspices of the Learned Society of Praxiology in the series Praxiology: The International Annual of Practical Philosophy and Methodology (Gasparski \& Ryan, 1996; Ryan, Gasparski \& Enderle, 2000; Loukola \& Gasparski, 2012; Airaksinen \& Gasparski, 2016).

The formation of the Silesian Centre for Business Ethics and Sustainable Development is another milestone event of the post-congress period. I would like to wish the center major achievements, and to its e-magazine-interesting articles and numerous readers.

\section{References}

Airaksinen, T., \& Gasparski, W. W. (Eds.). (2016). Desire: The concept and its practical context. London, New York: Routledge.

de Arruda, M. C., \& Rok, B. (Eds.) (2016). Understanding ethics and responsibilities in a globalizing world. Cham, Heidelberg, New York, Dordrecht, London: Springer.

Auspitz, J. L., Gasparski W., Mlicki, M., \& Szaniawski, K., (Eds.). (1992). Praxiologies and the Philosophy of Economics. New Brunswick-London: Transaction Publishers.

Bocheński, J. M. (1992). Wspótczesne metody myślenia. Poznań: W drodze.

\footnotetext{
${ }^{9}$ In December 2015, the conference was devoted to the ethics of e-business.

${ }^{10}$ The article The Ethical Issue of Corporate Governance and Management Science Theories sent to this congress by Gasparski was published in Global Perspectives on the Ethics of Corporate Governance (2006).
} 
Bocheński, J. M. (1993). Przyczynek do filozofii przedsiębiorstwa przemysłowego. In Logika i filozofia (pp. 162-186). Warszawa: Wydawnictwo Naukowe PWN.

Boulding, K. E. (1985). Etyka i biznes. In K. E. Boulding (Ed.), Ponad ekonomia (pp. 59-69). Warszawa: Państwowy Instytut Wydawniczy.

Boulding, K. E. (1989). Metodologie właściwe badaniom ekonomicznym. Prakseologia, 105(4), 25-47.

Bunge, M. (1999). Ethics and Praxiology as technologies. Society for Philosophy and Technology E-Journal, 4(4), 221-224.

Ćwieluch, J. (2016, February 3-9). Królowe i ofiary. Interview with a psychologist and a researcher of teenagers' behaviour, dr Małgorzatą Wójcik. Polityka, 6(3045), 32-34.

DeMartino, G. F. (2011). The economist's oath: On the need for and content of professional economic ethics. Oxford University Press.

Dietl, J., \& Gasparski, W. (Eds.). (1997). Etyka biznesu. Warszawa: Wydawnictwo Naukowe PWN.

Dylus, A. (2002). Erozja standardów etycznych w biznesie. In J. Mariański (Ed.), Kondycja moralna społeczeństwa polskiego (pp. 271-303). Kraków: Wydawnictwo WAM.

Filek, J. (2013). Społeczna odpowiedzialność biznesu jako nowa wersja umowy społecznej. Kraków: Księgarnia Akademicka.

Friedman, M. (1953). Essays in Positive Economics. University of Chicago Press.

Fryzel, B. (Ed.) (2015). The true value of CSR: Corporate identity and stakeholder perceptions. New York: Palgrave Macmillan.

Gasparski, W. (1993a). A philosophy of practicality: A treatise on the philosophy of Tadeusz Kotarbiński. Helsinki: Societas Philosophica Fennica.

Gasparski, W. (1993b). Design, science and philosophy: The praxiological perspective. In M. J. de Vries, N. Cross, \& D. P. Grant (Eds.), Design methodology and relationships with science (pp. 165-190). Dordrecht: Kluwer [Polish translation: (1995). Projektowanie, nauka i filozofia: perspektywa prakseologiczna. In M. Czarnocka (Ed.), Dziedzictwo logicznego empiryzmu (pp. 86-116). Warszawa: Instytut Filozofii i Socjologii, Polish Academy of Sciences].

Gasparski, W. (1996). Działalność gospodarcza z punktu widzenia filozofii: między prakseologią a etyką. Prakseologia, 1-4(130-133), 9-28.

Gasparski, W. (1997). Etyka biznesu - szkice do portretu. In J. Dietl, \& W. Gasparski (Eds.), Etyka biznesu (pp. 16-36). Warszawa: Wydawnictwo Naukowe PWN.

Gasparski, W. (2006). The ethical issue of corporate governance and management science theories. In G. J. (Deon) Rossouw, \& A. J. G. Sison, (Eds.), Global perspectives on the ethics of corporate governance (pp. 91-104). New York: Palgrave Macmillan.

Gasparski, W. (2009a). Fizyka i inżynieria ekonomii. In M. Rocki (Ed.), Jakość kształcenia ekonomicznego (pp. 55-59). Warszawa: Polskie Towarzystwo Ekonomiczne.

Gasparski, W. (2009b). Kultura organizacyjna i etos pracy. Referat wygłoszony na sesji panelowej Kongresu Kultury Polskiej. Kraków.

Gasparski, W. (2015). Czy ekonomiści powinni mieć kodeks etyczny? Postulaty, wątpliwości, propozycje. In B. Fiedor (Ed.), Nauki ekonomiczne: Stylizowane fakty a wyzwania współczesności (pp. 232-245). Warszawa: Polskie Towaszystwo Ekonomiczne. 
Gasparski, W. (2016). Krótka historia etyki biznesu tu i teraz. Etyka biznesu i zrówno-ważony rozwój. Interdyscyplinarne studia teoretyczno-empiryczne, 1, 21-35. https://www. polsl.pl/organizacje/SCEBIZR/Documents/Kuzior\%20Aleksandra\%20-\%20Etyka\%2 01-2016.pdf

Gasparski, W. (2017). From a study of practice to a philosophy of practicality: Tadeusz Kotarbiński's contribution to the Lvov-Warsaw school of philosophy. In A. Brożek, F. Stadler, \& J. Woleński (Eds.), The signifi-cance of the Lvov-Warsaw school in European culture (pp. 135-154). Cham: Springer.

Gasparski, W. (Ed.). (2008). Responsible management education. Warszawa: Wydawnictwa Akademickie i Profesjonalne.

Gasparski, W. (Ed.). (2013). Biznes, etyka, odpowiedzialność. Warszawa: Wydawnictwo Naukowe PWN.

Gasparski, W., \& Dietl, J. (2000). Etyka biznesu w działaniu. Doświadczenia i perspektywy. Warszawa: Wydawnictwo Naukowe PWN.

Gasparski, W., Lewicka-Strzałecka, A., Rok, B., \& Bąk, D. (2010). Portret polskiej etyki biznesu: fakty, oceny, propozycje. In W. Gasparski, \& B. Rok (Eds.), Ku obywatelskiej rzeczpospolitej gospodarczej (pp. 13-36). Warszawa: Poltext.

Gasparski, W., \& Rok, B. (Eds.). (2010). Ku obywatelskiej rzeczpospolitej gospodarczej. Warszawa: Poltext.

Gasparski, W., \& Ryan, L. V. (Eds.) (1996). Human action in business: Praxiological and ethical dimensions. London, New York: Routledge.

Gasparski, W., Lewicka-Strzałecka, A., Rok, B., \& Szulczewski, G. (Eds.). (2002). Etyka biznesu w zastosowaniach praktycznych: Inicjatywy, programy, kodeksy. Warszawa: CEBI \& Biuro Stałego Koordynatora ONZ w Polsce.

Grosfeld, J. (Ed.). (1985). Ponad ekonomia. Warszawa: Państwowy Instytut Wydawniczy.

Haidt, J. (2014). Prawy umyst: Dlaczego dobrych ludzi dzieli religia i polityka? Sopot: Smak Słowa.

Hiż, H. (1992). Praxiology, society and ethics. In J. L. Auspitz, W. Gasparski, M. Mlicki, \& K. Szaniawski, (Eds.), Praxiologies and the Philosophy of Economics (pp. 421-429). New Brunswick-London: Transaction Publishers.

Kamiński, R. \& Sójka, J. (Eds.) (2013). Ekonomiczne i etyczne aspekty kryzysu gospodarczego. Poznań: Polskie Towarzystwo Ekonomiczne.

Kotarbiński, T. (2003). Prakseologia, Part II. In Dzieła wszystkie (ch. 4, Elementy metodologii dyscyplin praktycznych, pp. 253-355). Wrocław: Ossolineum.

Kuraszko, I. (Ed.) (2014). Etyka przywództwa: Ujęcie interdyscyplinarne. Warszawa: Difin.

Loukola, O., \& Gasparski, W. W. (Eds.). (2012). Environmental political philosophy. New Brunswick, London: Transaction Publishers.

Luijk, H. J. L, van (2000). Europejska Sieć Etyki Biznesu 1987-1997: Krótka historia obiecujących lat [EBEN 1987-1997: A short history of the promissing years]. In W. Gasparski, \& J. Dietl (Eds.), Etyka biznesu w działaniu. Doświadczenia I perspektywy (pp. 16-22). Warszawa: Wydawnictwo Naukowe PWN.

MacIntyre, A. (1996). Dziedzictwo cnoty: Studium z teorii moralności. Warszawa: Wydawnictwo Naukowe PWN.

Pańkow, W., Rok, B., Strumińska-Kutra, M. \& Woźniczko, J. (2010). Oblicza społecznej odpowiedzialności przedsiębiorstw. Warszawa: Wydawnictwo Naukowe Scholar. 
Rok, B. (2013). Podstawy odpowiedzialności społecznej w zarządzaniu. Warszawa: Poltext. Rossouw, D., \& Stückelberger, Ch. (Eds.). (2012). Global survey of Business Ethics in training, teaching and research. Geneva: Globethics.net.

Ryan, L. V., Gasparski, W. W., \& Enderle, G. (Eds.). (2000). Business students focus on ethics. London, New York: Routledge.

Simon, H. A. (1989). Metodologiczne podstawy ekonomii. Prakseologia, 105(4), 129-152.

Stróżewski, W. (2012). O przeświadczeniach. Przegląd Filozoficzny, 21(2), 9-28. 